Table 2 E-gene and RdRP RT-PCR results with different oligonucleotide combinations

\begin{tabular}{|c|c|c|c|c|c|}
\hline $\begin{array}{l}\text { Assay and } \\
\text { oligonucleotides }\end{array}$ & Notes & $\begin{array}{l}\text { SARS-CoV-2 positive } \\
\text { clinical sample } 1(\mathrm{Ct})\end{array}$ & $\begin{array}{l}\text { SARS-CoV-2 positive } \\
\text { clinical sample } 2(\mathrm{Ct})\end{array}$ & $\begin{array}{l}\text { NTC } 1 \\
(\mathrm{Ct})\end{array}$ & $\begin{array}{c}\text { NTC } 2 \\
(\mathrm{Ct})\end{array}$ \\
\hline \multicolumn{6}{|l|}{ E-gene } \\
\hline $\mathrm{F} 1 / \mathrm{R} 2+$ probe $\mathrm{Y}$ & Original primer set with probe from supplier Y & 26.37 & 20.42 & ND & ND \\
\hline $\mathrm{F} 1 / \mathrm{R} 2+$ probe $\mathrm{X}$ & Original primer set with probe from supplier $\mathrm{X}$ & 29.04 & 22.59 & 35.44 & 37.05 \\
\hline $\mathrm{F} 1 /$ altR $2+$ probe $\mathrm{X}$ & Alternative primer combinations with probe from & 29.51 & 23.15 & ND & ND \\
\hline $\mathrm{F} 1 /$ altR $3+$ probe $\mathrm{X}$ & supplier X & 29.3 & 23.25 & ND & ND \\
\hline altF2/R2 + Probe $\mathrm{X}$ & & 28.85 & 22.94 & ND & ND \\
\hline altF2/altR2 + Probe X & & 29.49 & 23.5 & ND & ND \\
\hline altF2/altR3 + Probe X & & 30.44 & 23.93 & ND & ND \\
\hline altF2/altR4 + Probe X & & 29.86 & 23.76 & ND & ND \\
\hline altF3/R2 + Probe $\mathrm{X}$ & & 29.32 & 23.2 & ND & ND \\
\hline altF3/altR2 + Probe X & & 29.87 & 23.84 & ND & ND \\
\hline altF3/altR3 + Probe X & & 30.51 & 24.24 & ND & ND \\
\hline altF3/altR4 + Probe X & & 30.22 & 24.24 & ND & ND \\
\hline altF4/R2 + Probe X & & 29.9 & 23.8 & ND & ND \\
\hline altF4/altR3 + Probe $X$ & & 30.48 & 24.29 & ND & ND \\
\hline altF4/altR4 + Probe X & & 30.75 & 24.72 & ND & ND \\
\hline \multicolumn{6}{|l|}{ RdRP } \\
\hline $\mathrm{F} 2 / \mathrm{R} 1+$ probe $\mathrm{Y}$ & Original primer set with probe from supplier Y & 29.48 & 23.97 & ND & ND \\
\hline $\mathrm{F} 2 / \mathrm{R} 1+$ probe $\mathrm{X}$ & Original primer set with probe from supplier $\mathrm{X}$ & 26 & 24.31 & 26.24 & 26.11 \\
\hline $\mathrm{F} 2 /$ altR $2+$ probe $\mathrm{X}$ & Alternative primer combinations with probe from & ND & 28.74 & ND & ND \\
\hline $\mathrm{F} 2 /$ altR $3+$ probe $\mathrm{X}$ & supplier X & 29.27 & 23.63 & ND & ND \\
\hline altF3/R1 + probe $\mathrm{X}$ & & ND & 26.14 & ND & ND \\
\hline altF3/altR2 + probe $X$ & & 28.49 & 22.97 & ND & ND \\
\hline altF3/altR3 + probe $X$ & & 29.06 & 23.46 & ND & ND \\
\hline altF $4 / \mathrm{R} 1+$ probe $\mathrm{X}$ & & 31.29 & 25.72 & ND & ND \\
\hline altF4/altR2 + probe $X$ & & 28.64 & 23.05 & ND & ND \\
\hline altF4/altR3 + probe $X$ & & 29.31 & 23.36 & ND & ND \\
\hline
\end{tabular}

alt, alternative; Ct, cycle threshold; F, forward primer; ND, not detected; R, reverse primer.

and delays associated with the pandemic, and would have left our laboratory in a precarious position had we not also ordered probes from supplier Y. We affirm that synthetic controls can be useful as positive control material for rare or emergent diseases but should be manufactured and used carefully. Oligonucleotide suppliers should consider how to better handle such requests.

Acknowledgements: We thank Pathology Queensland staff for their assistance with provision of samples for this study.

Conflicts of interest and sources of funding: $\mathrm{PH}$ reports financial support from Sandoz, MSD, Shionogi and Pfizer outside the submitted work. DW reports financial support from SpeeDx Pty Ltd outside the submitted work. The authors state that there are no conflicts of interest to disclose.

Claire Y. T. Wang ${ }^{1}$, Cameron Buckley ${ }^{2}$, Cheryl Bletchly ${ }^{3}$, Patrick Harris ${ }^{2,3}$, David Whiley ${ }^{2,3}$

${ }^{1}$ Centre for Children's Health Research, Children's Health Queensland, Brisbane, Qld, Australia; ${ }^{2}$ The University of Queensland Centre for Clinical Research, The University of Queensland, Brisbane, Qld, Australia; ${ }^{3}$ Pathology Queensland Central Laboratory, Brisbane, Qld, Australia

Contact Claire Y. T. Wang.

E-mail: claire.wang@uq.edu.au

1. Guo YR, Cao QD, Hong ZS, et al. The origin, transmission and clinica therapies on coronavirus disease 2019 (COVID-19) outbreak - an update on the status. Mil Med Res 2020; 7: 11.
2. Lv M, Luo X, Estill J, et al. Coronavirus disease (COVID-19): a scoping review. Euro Surveill 2020; 25: 2000125.

3. Rabi FA, Al Zoubi MS, Kasasbeh GA, et al. SARS-CoV-2 and coronavirus disease 2019: what we know so far. Pathogens 2020; 9: 231.

4. World Health Organisation (WHO). WHO Director-General's opening remarks at the media briefing on COVID-19. 2020; Cited 2 Jun 2020. https://www.who.int/dg/speeches/detail/who-director-general-s-openingremarks-at-the-media-briefing-on-covid-19-11-march-2020

5. Corman VM, Landt O, Kaiser M, et al. Detection of 2019 novel coronavirus (2019-nCoV) by real-time RT-PCR. Euro Surveill 2020; 25: 2000045.

6. World Health Organisation (WHO). Coronavirus disease (COVID-19) pandemic. 2020. https://www.who.int/emergencies/diseases/novelcoronavirus-2019

7. Smith G, Smith I, Harrower B, et al. A simple method for preparing synthetic controls for conventional and real-time PCR for the identification of endemic and exotic disease agents. J Virol Methods 2006; 135: 229-34.

8. Conte J, Potoczniak MJ, Tobe SS. Using synthetic oligonucleotides as standards in probe-based qPCR. Biotechniques 2018; 64: 177-9.

DOI: https://doi.org/10.1016/j.pathol.2020.08.002

\section{Histopathology of cutaneous COVID-19 lesion: possible SARS- CoV-2 cytopathogenic effect}

Sir,

On 1 April 2020 a 66-year-old woman was seen in the emergency room for dyspnoea. She also suffered from diffuse pain and severe fatigue for two days and headache, fever, dysgeusia and agenesis for four days. She had received a $1 \mathrm{~g}$ dose of azithromycin, with no improvement. Chest computed 
tomography (CT) scan showed bilateral ground glass opacities compatible with COVID-19, although the nasopharyngeal polymerase chain reaction (PCR) was negative. She was sent home to be confined and treatment with amoxicillinclavulanate and doxycycline was initiated, without improvement. On 6 April she began treatment with

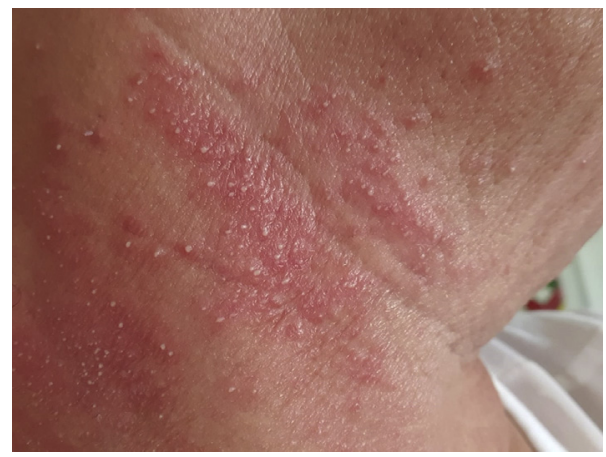

Fig. 1 Clinical picture showing the erythematous and pustular rash of the neck.
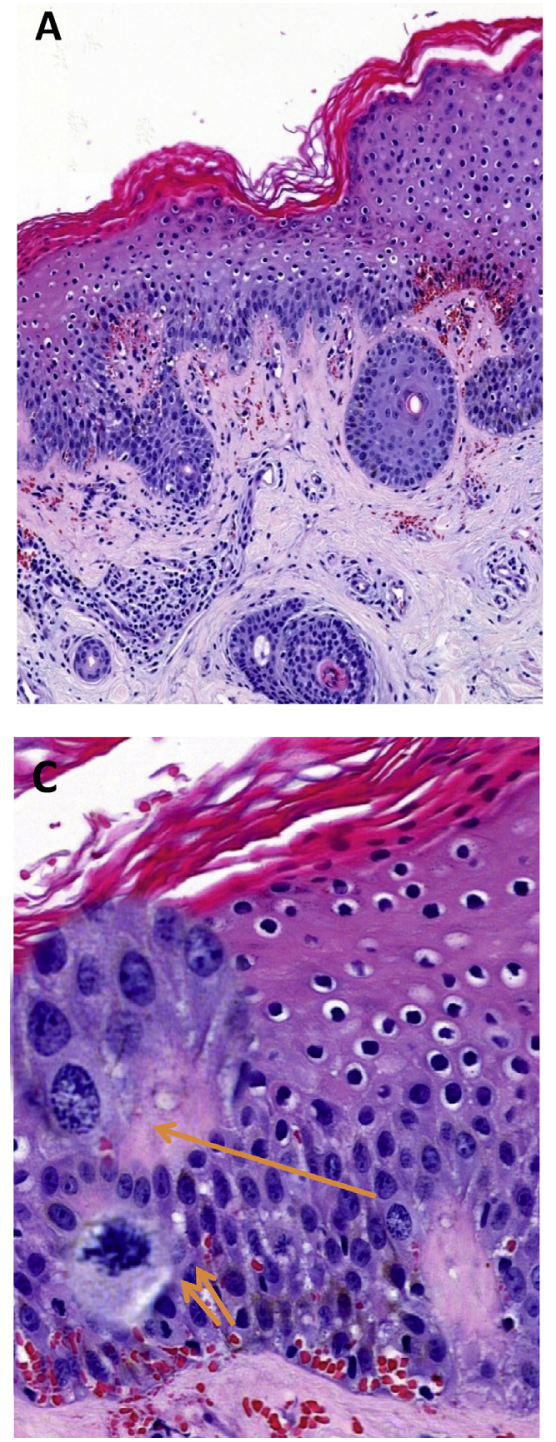

prednisolone $60 \mathrm{mg} / \mathrm{day}$. Three days later the patient reported cheilitis. The next day an erythematous, pustular, nonpruriginous rash appeared on the neck and slowly spread to the upper trunk (Fig. 1). The possibility of a drug reaction was raised, but the rash improved without interruption of antibiotic therapy. A skin biopsy was performed on the neck on 12 April. Clinical signs improved significantly from 13 April onwards.

The histological examination of the cutaneous lesion using hematoxylin and eosin (H\&E) staining showed hyperkeratosis acanthotic epidermis with focal parakeratosis (Fig. 2A). Some superficial and intermediate keratinocytes had hyperchromatic nuclei and clear peri-nuclear halo (koilocyte-like cells). The cellular modifications were more marked in the basal layers of the epidermis. We observed a moderate cellular atypia with an increase in cell size and cytoplasm vacuolation (foamy degeneration), enlarged nuclei, often vesicular in appearance, with prominent nucleoli. Some nuclei had diffused fine chromatin, others had coarse-looking chromatin condensations. We observed an increased number of mitoses in the
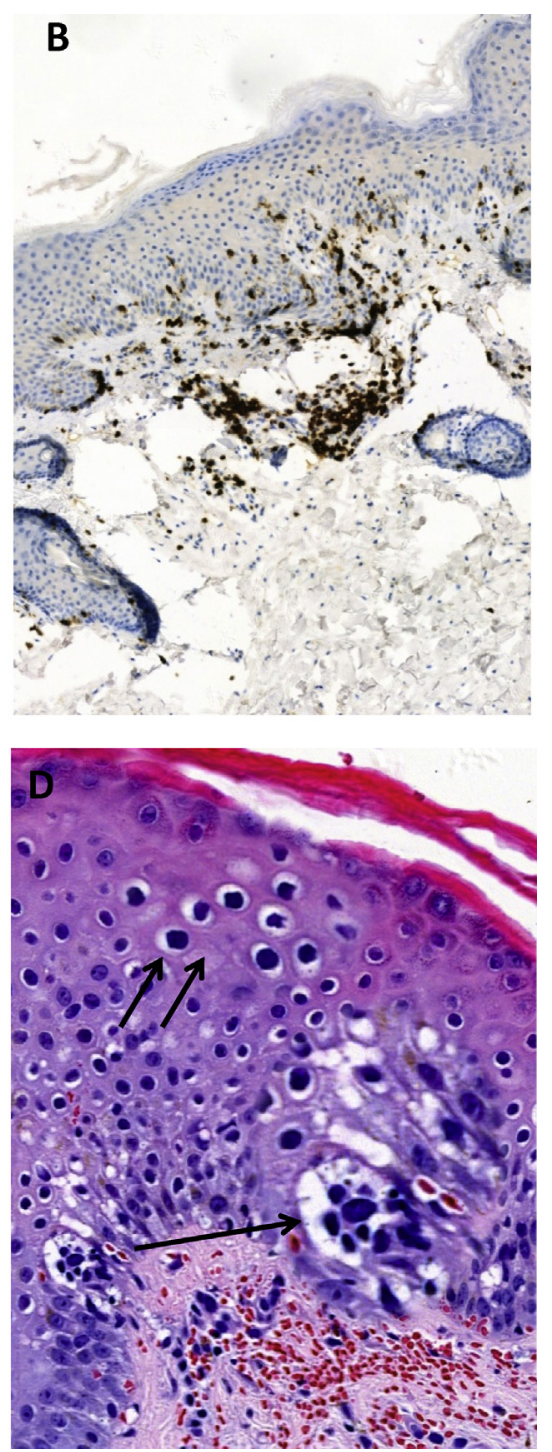

Fig. 2 Histological findings of cutaneous COVID-19 lesion. (A) Acanthotic epidermis with moderate perivascular lymphocytic infiltrate in the dermis (H\&E). (B) The majority of lymphocytes are of T CD3+ phenotype (IHC). (C) The nuclear and chromatin modifications (H\&E stain, one orange arrow and focus spot), and an atypical mitosis (H\&E stain, two orange arrows and focus spot). (D) Foamy cytoplasmic vacuolation (H\&E stain, one black arrow and focus spot), and koilocyte-like perinuclear halo (H\&E stain, one black arrow and focus spot). 
basal layer of the epidermis, some of which were atypical (Fig. 2C,D). The papillary dermis was slightly oedematous with dilated small vessels associated with extravasated erythrocytes. In the superficial and reticular dermis, a moderate perivascular inflammatory infiltrate was observed, consisting mainly of lymphocytes. Neutrophils were visible mainly in the lumen of vessels, without appearance of leukocytoclastic vasculitis. The nuclei of some endothelial cells appeared swollen and turgid. We did not observe inclusion bodies or syncytial polynuclear giant cells, neither in epidermal keratinocytes nor in vascular endothelial cells.

A complementary immunohistochemical study revealed a prominent $\mathrm{T}$ lymphocytes infiltrate $(\mathrm{CD} 3+)$, mostly $\mathrm{T}$ 'helper' CD4+ $(65 \%)$ with some T 'cytotoxic' CD8+ (35\%) (Fig. 2B). In addition, there was a discrete intraepidermal T lymphocytic exocytosis (CD3+ and CD4+), and very few B lymphocytes $(\mathrm{CD} 20+)$ in the upper dermis.

These unusual epidermal histological changes (Fig. 2C,D) in the absence of significant interface dermo-epidermal inflammatory infiltrate or leukocytoclastic vasculitis may correspond to a viral cytopathogenic effect.

Since the first clinical reports of COVID-19 in China, this infection has been linked to several cutaneous signs: maculopapular rash, urticaria, chickenpox-like lesions, ${ }^{1,2}$ pseudo chilblains, ${ }^{3}$ dengue-like rash with petechiae, ${ }^{4}$ livedo or necrosis. ${ }^{5}$ Case reports of skin symptoms in COVID-19 often lack clinical images and/or histology. Unspecific histological findings have been reported so far, including a perivascular infiltrate of lymphocytes and dermal oedema, ${ }^{6}$ or undetailed signs consistent with viral infection.

In this letter, we report a pustular and erythematous rash, another example of the various skin presentations of COVID19. This disease has already been linked to rashes mimicking drug related exanthema. ${ }^{7}$ This rash could have been mistaken for skin drug reaction but the clinical improvement despite continuation of the treatment is not in favour of this hypothesis, nor is the histology. More importantly, we report histological images of possible cytopathogenic signs of SARS-CoV-2 infection in cutaneous tissue, suggesting a direct effect of the viral infection on skin cells. Herpes-like aspects have recently been observed in keratinocytes of an infected patient in Italy. ${ }^{8}$ In addition, the presence of the angiotensin converting enzyme 2 (ACE2) and proteases already implicated in SARS-CoV-2 infection in the skin would allow the infestation of cutaneous tissue by the virus. ${ }^{9-11}$ Obviously, the formal confirmation of such a hypothesis requires the detection of the virus or its particles in the infected epidermis using immunohistochemistry or PCR technique.

Conflicts of interest and sources of funding: The authors state that there are no conflicts of interest to disclose.

\section{Kinan Drak Alsibai ${ }^{1,2}$, Celine Michaud ${ }^{3}$, Alex Taquet $^{3}$, Magalie Demar $^{4,5}$, Romain Blaizot ${ }^{4,6}$}

${ }^{1}$ Department of Pathology, Cayenne Hospital Center Andree Rosemon, Cayenne, French Guiana; ${ }^{2}$ Center of Biological Resources (CRB Amazonie), Cayenne Hospital Center Andree Rosemon, Cayenne, French Guiana; ${ }^{3}$ Health Centres for Remote Areas, Cayenne Hospital Center Andree Rosemon, Cayenne, French Guiana; ${ }^{4}$ EA 3593 Ecosystèmes
Amazoniens et Pathologies Tropicales, University of French Guiana, Cayenne, French Guiana; ${ }^{5}$ Laboratory of Parasitology-Mycology, Cayenne Hospital Center Andree Rosemon, Cayenne, French Guiana; ${ }^{6}$ Department of Dermatology, Cayenne Hospital Center Andree Rosemon, Cayenne, French Guiana

Contact: Dr Kinan Drak Alsibai.

E-mail: kdrak.alsibai@doctor.com

1. Recalcati S. Cutaneous manifestations in COVID-19: a first perspective. J Eur Acad Dermatol Venereol 2020; 34: e212-3.

2. Marzano AV, Genovese G, Fabbrocini G, et al. Varicella-like exanthem as a specific COVID-19-associated skin manifestation: multicenter case series of 22 patients. J Am Acad Dermatol 2020; 83: 280-5.

3. Hedou M, Carsuzaa F, Chary E, et al. Comment on "Cutaneous manifestations in COVID-19: a first perspective" by Recalcati S. J Eur Acad Dermatol Venereol 2020; 34: e299-300.

4. Joob B, Wiwanitkit V. COVID-19 can present with a rash and be mistaken for dengue. J Am Acad Dermatol 2020; 82: e177.

5. Galván Casas C, Català A, Carretero Hernández G, et al. Classification of the cutaneous manifestations of COVID-19: a rapid prospective nationwide consensus study in Spain with 375 cases. Br J Dermatol 2020; 183: 71-7.

6. Fernandez-Nieto D, Ortega-Quijano D, Segurado-Miravalles G, et al. Comment on: cutaneous manifestations in COVID-19: a first perspective. Safety concerns of clinical images and skin biopsies. J Eur Acad Dermatol Venereol 2020; 34: e252-4.

7. Mahé A, Birckel E, Krieger S, Merklen C, Bottlaender L. A distinctive skin rash associated with coronavirus disease 2019? J Eur Acad Dermatol Venereol 2020; 34: e246-7.

8. Gianotti R, Veraldi S, Recalcati S, et al. Cutaneous clinico-pathological findings in three COVID-19-positive patients observed in the metropolitan area of Milan, Italy. Acta Derm Venereol 2020; 100: adv00124.

9. Grzegrzolka J, Swiatko K, Pula B, et al. ACE and ACE2 expression in normal and malignant skin lesions. Folia Histochem Cytobiol 2013; 51 232-8.

10. Ziegler CGK, Allon SJ, Nyquist SK, et al. SARS-CoV-2 receptor ACE2 is an interferon-stimulated gene in human airway epithelial cells and is detected in specific cell subsets across tissues. Cell 2020; 181 $1016-35$.

11. Drak Alsibai K. Expression of angiotensin-converting enzyme 2 and proteases in COVID-19 patients: a potential role of cellular FURIN in the pathogenesis of SARS-CoV-2. Med Hypotheses 2020; 143: 109893.

DOI: https://doi.org/10.1016/j.pathol.2020.07.003

\section{Is prostate infarction and acute urinary retention a possible complication of severe COVID-19 infection?}

Sir,

Since the beginning of the COVID-19 pandemic in 2019, international efforts have been made to discover and describe the clinical characteristics, epidemiology, prevention and treatment of this disease caused by SARS-CoV-2 (severe acute respiratory syndrome Coronavirus 2).

The virus is involved with the damage of several organs, such as lungs, kidneys and brain, especially in critical patients. This is due to direct injury and, more importantly, by the induction of a severe proinflammatory state, labelled cytokine storm. $^{1-3}$ Interestingly, men have been more severely affected by the disease, especially the elderly. ${ }^{4}$ This fact has not yet been clarified, but specific factors in the viral pathogenicity could shed light on it. 